\title{
U.S. Geological Survey Programs in Colorado
}

\section{U.S. Department of the Interior - U.S. Geological Survey}

The U.S. Geological Survey (USGS) has served as the Nation's principal collector, repository, and interpreter of earth science data for more than a century. In this capacity, the USGS in Colorado works in partnership with more than 90 local, State, and Federal agencies. Cooperative activities include water-resources data collection, interpretive water-availability and water-quality studies, mineral-resource assessments, and mapping. In activities with local and State agencies, USGS and non-Federal funds are typically matched equally. The USGS also is involved with several community outreach activities, which include educational presentations at schools and information booths at community events. The USGS also supports the Colorado Water Resource Research Institute, which conducts research, education, and information and technology-transfer programs. This Fact Sheet describes some of the current USGS activities in Colorado.

\section{Geologic Mapping Along I-70}

Rapid growth along the I-70 corridor in the western part of the State between the Utah border and the Frisco-Dillon area has prompted the USGS and the Colorado Geological Survey to form cooperative geologic mapping teams. At least 36 detailed geologic maps of the corridor are planned over about a 5-year period. Many geologic hazards, such as landslides, debris flows, and sinkholes, can be avoided if the information on detailed geologic maps is used to make land-use decisions. People in Mesa, Garfield, Eagle, and Summit Counties and city, State, and Federal agencies can use these maps to make decisions intended to mitigate or avoid geologic hazards, and, therefore, potentially save lives, money, and property.

\section{Landslide Hazards}

Huge, ancient landslides cover mountain sides throughout western Colorado; many of these slides are near towns, recreational facilities, railroads, and major highways. If any of these landslides were reactivated by human activities, earthquakes, or climate change, then nearby towns or facilities could be destroyed. USGS scientists in Lake City and
Grand Mesa are studying large, ancient and modern landslides. Through these studies, the USGS can document many of the conditions that caused the landslides and formulate models to predict where and when landslides can occur or be reactivated by changing climate or earthquakes.

\section{Oil-Resource Assessments}

Working with the U.S. Forest Service (USFS) and the State of Colorado, the USGS assessed the petroleum-resource potential of the White River National Forest. This assessment provided these agencies information to formulate development plans that consider natural ecosystem preservation.

The USGS, in cooperation with the U.S. Department of Energy (DOE), recently completed an assessment of the petroleum potential of two Naval Oil Shale Reserves in Colorado.

\section{National Water-Quality Assessment Program}

The long-term goals of the National WaterQuality Assessment (NAWQA) Program are to describe the status and trends in the quality of a large, representative part of the Nation's surface- and ground-water resources and to identify the natural and human factors that affect their quality. The NAWQA Program produces water-quality information that is useful to policymakers and water managers at the local, State, and national levels.

NAWQA Program studies of three river basins in Colorado- the South Platte, the Upper Colorado, and the Rio Grande-are underway; another, the upper Arkansas, is planned (fig. 1). Communication and coordination among the USGS and the watermanagement and other water-resource agencies are essential to the NAWQA studies in the State. As results become available, the findings are distributed in technical and public information reports to local, State, and Federal agencies.

\section{Coal-Bed Methane Resources}

In less than 10 years, the San Juan Basin of New Mexico and Colorado has become the

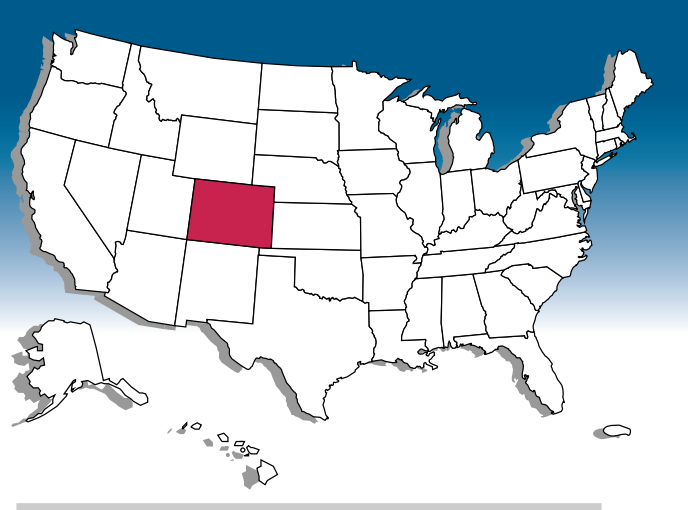

Index of Subjects

Geologic mapping Along 1-70

Landslide Hazards

Oil-Resource Assessments

National Water-Quality Assessment Program

Coal-Bed Methane Resources

Studies of Contamination at U.S. Departments of Energy and Defense Sites

Studies of Stream Contamination From Mine Waste

Environmental Assessments of Abandoned Mine Lands

Research on Biological Systems

Irrigation Water Quality

Topographic Mapping

Digital Raster Graphics

Watershed-Modeling Systems Initiative in the San Juan River Basin

Drought History and Climatic Change in Eastern Colorado

Effects of Acid Precipitation on Rocky Mountain Lakes and Streams

Information Centers

Change Over Time

Collection of Hydrologic Data

largest coal-bed methane field in production in the world. Total coal-bed methane resources for the Basin have been estimated to be 50 trillion cubic feet of gas, and as much as one-half of that amount is considered to be recoverable. For the first time, the amount of gas produced in 1994 from coal beds of the Fruitland Formation surpassed the production of gas from the Basin's conventional sandstone reservoirs. The rapid development of the coal-gas resources was made possible by detailed studies of the Fruitland coal beds published by the USGS and the Colorado Geological Survey in the 1970's.

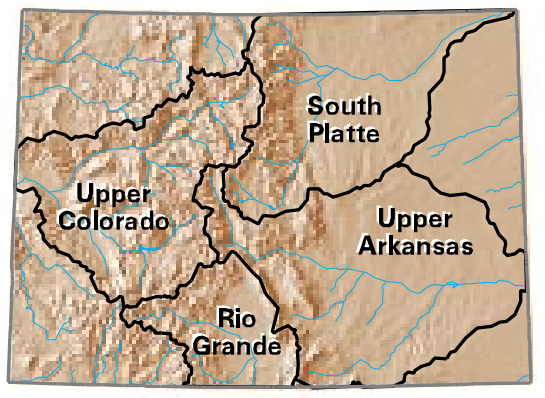

Figure 1. National Water-Quality Assessment Program study units in Colorado shown with topography. 
Natural gas seeps from Fruitland coal-bed outcrops have been reported in La Plata County for many years; some of these reports predate development. No data existed to evaluate whether the coal-bed gas development was contributing to the seepage. In 1995, the USGS, in cooperation with the Bureau of Land Management (BLM), the Colorado Oil and Gas Conservation Commission, La Plata County, and the Southern Ute Indian Tribe, began a study of the gas seeps in La Plata County. In addition to surface geologic mapping and fracture studies, the USGS is determining whether there is a correlation between the surface coal beds in the seep areas and the underground coal beds that produce coal-bed methane near the gas-seep areas. The USGS also uses the maps of La Plata County being produced by the Colorado Geological Survey as part of their STATEMAP program. These studies of the coal-gas seep areas in La Plata County are part of an ongoing USGS basinwide study of coal-bed methane.

\section{Studies of Contamination at U.S. Department of Energy and Defense Sites}

Several DOE and U.S. Department of Defense sites in Colorado have some level of contamination caused by past production, storage, or destruction of chemical agents, munitions, or radioactive materials. Near some of the sites, radioactive and chemical contaminants have migrated into drinkingwater supplies or have contaminated soils. The USGS is collecting hydrologic data and conducting investigative studies at the Rocky Mountain Arsenal and the Rocky Flats Environmental Technology Site near Denver and the Pueblo Depot Activity near Pueblo. The purposes of the studies include characterization of the hydrology of the sites, definition of the extent of contamination, evaluation of monitoring networks, determination of contaminant-transport mechanisms, and prediction of the fate of contaminants.

\section{Studies of Stream Contamination From Mine Waste}

Significant water-quality problems have resulted from wastes related to metal mining in the Rocky Mountains. The USGS is conducting investigations near Summitville in the Alamosa River Basin, near Leadville in the upper Arkansas River Basin, in the upper Animas River Basin near Durango, and along Clear Creek west of Denver. The studies assess the extent of the contamination; define background conditions; aid local, State, and Federal agencies in making decisions on appropriate remediation strategies; determine the processes involved in the transport of contaminants from the waste sites; and predict the movement of the contaminants. Information from these studies is being used by the U.S. Environmental Protection Agency (USEPA) to help site remediation; the State of Colorado, Federal land-management agencies (BLM, USFS), and the mining industry to help understand and prevent similar environmental problems at other mines; and downstream water users, such as farmers, water conservancy districts, and wildlife refuges, to evaluate potential effects of mine-waste sites on agriculture and wildlife habitat.

\section{Environmental Assessments of Abandoned Mine Lands}

The BLM and the USFS have been charged with identifying and prioritizing for remediation tens of thousands of abandoned mine sites in Colorado. The USGS, in cooperation with the BLM and the Colorado Geological Survey, has developed a geologybased regional screening process that was used to identify and rank Colorado mining districts according to their likely minedrainage hazards. This screening process allows land-management agencies to focus their remedial efforts on mining districts with the greatest potential for environmental problems, thereby avoiding costly field assessments of all mining districts. The BLM, the USFS, and other Federal agencies are proposing that the USEPA use geologybased regional screening to help assign and assess stormwater permits for abandoned mine sites on public lands. The mining industry also can use this process to predict, plan for, and mitigate the environmental consequences of mineral-resource development.

\section{Research on Biological Systems}

The USGS Biological Resources Division (formerly the National Biological Service) has three major stations in Colorado. The Midcontinent Ecological Science Center in Fort Collins studies the effects of native and introduced grazing animals on ecosystems; mountain plover, black-footed ferret, and prairie dog ecosystems; declining amphibian populations; global climate change; the Colorado squawfish; and the effects of the Conservation Reserve Program on Great Plains ecosystems. Other research includes aquatic and riparian ecology, atmospheric and watershed ecosystem change, vertebrate ecology, habitat modeling, remote sensing and geographical information system mapping, socioeconomic issues, and air quality impacts on U.S. Department of the Interior (DOI) lands.
The Information and Technology Office's Technology Transfer Center (TTC) in Lakewood is implementing the National Biological Information Infrastructure so that users can retrieve and integrate electronic biological data directly from different sources simultaneously on the Internet. The TTC also develops data and standards for biological resources and partnerships for natural resources technology and information transfer. The TTC's home page can be viewed at: http://www.nbs.gov/ttc/

The Colorado Cooperative Fish and Wildlife Research Unit at Colorado State University conducts research on vegetation, large mammals, fisheries, and landscape ecology.

\section{Irrigation Water Quality}

Since 1985 , the DOI has been studying the effects of Federal irrigation projects in the Western United States. These studies have been done to determine if irrigation drainage is causing problems related to human health, water quality, and fish and wildlife resources. Beginning in 1987, the USGS, in cooperation with the U.S. Fish and Wildlife Service, the Bureau of Indian Affairs, and the Bureau of Reclamation (BOR), has studied irrigation drainage in the lower Gunnison, the Uncompahgre, the Dolores, and the Los Pinos Rivers; Grand Valley in western Colorado; and the Arkansas River Basin in the eastern part of the State. The USGS found high concentrations of selenium in water and sediment in some of the irrigated areas. Because selenium can have adverse effects on fish and wildlife, investigations are continuing in the lower Gunnison River Basin and the Grand Valley to determine if measures can be implemented to mitigate selenium contamination. Although the emphasis has been on determining the effects of selenium on fish and wildlife, results of the investigations will aid water-resources managers and planners in developing mitigation measures that could include methods of improving irrigation practices, conserving water, and improving the water quality of the Colorado and the Arkansas Rivers.

\section{Topographic Mapping}

Among the most popular and versatile products of the USGS are its 1:24,000-scale topographic maps (1 inch on the map represents 2,000 feet on the ground). These maps show natural and cultural features of the landscape, such as lakes and streams, highways and railroads, boundaries, and geographic names. Colorado is covered by 1,926 maps at this scale. These maps have long been favorites with the general public for outdoor uses, 
as well as scientists and engineers for conventional technical applications. Today, scientists and engineers increasingly depend on digital (computerized) base maps for their research and analyses. The USGS is working to ensure the availability of accurate digital cartographic data for the Nation to facilitate ground-water and hazards studies, and landand resource-management activities.

In summer 1995, the Rocky Mountain Mapping Center moved into newly renovated office space on the Denver Federal Center in Building 810. The move allowed the Center to improve service to customers by consolidating all Denver-based production, research, and distribution operations into a single facility. The Center is responsible for the development of cartographic and geographic data and applications for the Western United States and for the dissemination and sales of published mapping information.

\section{Digital Raster Graphics}

Digital raster graphics (DRG; scanned topographic maps) are being produced in cooperation with several Federal, State, and local agencies for more than 1,000 of the 1:24,000-scale USGS topographic maps of Colorado. DRG's in progress in the State are shown in figure 2. DRG's are used as map bases or backdrops on which other information can be overlaid so that the other information can be combined with the familiar USGS topographic map. Users now combine these products manually on mylar or paper maps; DRG's will allow users to automate processes and to increase efficiency.

The DRG's can be used in many ways. The BLM can use DRG's in its Emergency Fire Suppression Program. The boundary of a fire can be mapped by collecting global positioning system points, and the outline can then be overlaid on the DRG for reference to the terrain. This information helps helicopter pilots and firefighters plan their method of fighting a fire. The Colorado Division of Wildlife can use DRG's as a back-

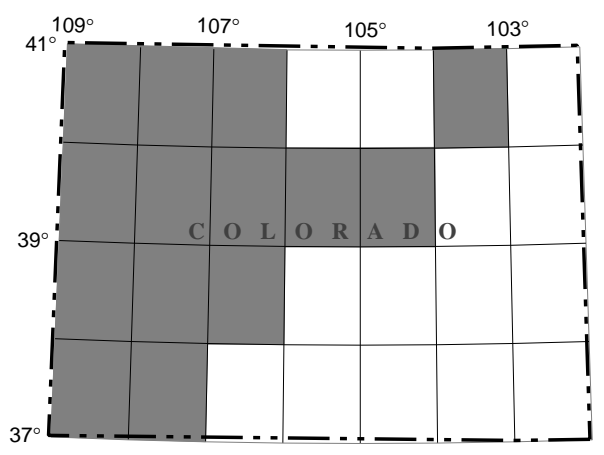

Figure 2. Digitial Raster Graphics in progress. drop to overlay boundaries for its propertymanagement program. Wildlife managers also can display point locations on the DRG to show wildlife distribution.

\section{Watershed-Modeling Systems Initiative in the San Juan River Basin}

Competition among users of the water resources in many Western drainage basins has increased pressure on water managers to provide relevant, near real-time assessments of water availability and use. Hydrologic and water-management models help managers develop these assessments. The purpose of this initiative is to develop, test, and implement water-resource models and integrated data-management systems that are designed to help manage the water-related infrastructure. This study is a collaboration between the USGS and the BOR and focuses on water-management issues in the San Juan River Basin, which is a tributary to the Colorado River. The Basin provides a diverse physical and hydrologic setting for testing and implementing water-resource models.

\section{Drought History and Climatic Change in Eastern Colorado}

Droughts have occurred in some parts of the Great Plains of eastern Colorado in nearly every decade of this century; droughts were severe in the 1930's, 1950's, and 1970's. Massive dust storms spawned by wind erosion during drought periods threaten the health, comfort, and livelihood of large segments of the population for long distances downwind. During the 1930's, blowing dust closed highways and railroads, cut off power, and blocked the Sun. Aircraft were adversely affected by dust carried aloft. In the 1990's, this impact is more serious because of modern air traffic.

USGS scientists are studying the distribution and history of windblown sediment in eastern Colorado to improve understanding of the frequency and cause of droughts in the Great Plains, the geological factors that control wind erosion, and the potential impact of climatic change on water supplies, soil erosion, and land-use practices. These studies indicate that droughts much more severe than any of the historic droughts are possible under the present climate.

\section{Effects of Acid Precipitation on Rocky Mountain Lakes and Streams}

To determine which Rocky Mountain lakes and streams are most at risk for acid precipitation, the USGS has determined the chemistry of the snowpack and the lakes and streams fed by snowmelt. The chemistry of the snowpack determines how acidic the snowmelt that supplies water to these aquatic systems becomes. The chemistry of the lakes and streams determines how susceptible these systems are to damage by acidic snowmelt. The most acidic snow in the Rocky Mountains falls in northern Colorado in and near the Mount Zirkel Wilderness Area. Because of the geology, lakes and streams of the Mount Zirkel Wilderness Area are among the most sensitive to acidic precipitation in the Rocky Mountains. Thus, in this area, the most acidic snowpack overlaps the most sensitive aquatic systems. The USGS, is working with local, State, and Federal agencies, as well as with industry and environmental groups, to determine what damage might have occurred or is likely to occur in the Wilderness Area. One of the possible effects is damage to trout and amphibian populations.

\section{Information Centers}

The USGS National Earthquake Information Center (NEIC) in Golden collects, processes, and distributes information about more than 20,000 seismic events each year. This information is distributed as alerts, bulletins, and routine catalogs to Federal and State emergency-management officials, criticalfacilities operators, news media, the general public, and the earthquake-research community. These catalogs of recent and historical earthquake information are used in earthquake-hazards assessments. To fulfill its mission, the NEIC has developed and is deploying the U.S. National Seismograph Network (USNSN), which, when completed, will consist of about 60 seismograph stations nationwide. The USNSN monitors nationwide seismicity, provides early notification of seismic events to national emergency-services personnel, maintains an archive of high-quality digital data on national seismicity, and provides public information on earthquakes.

The USGS's Earth Science Information Center (ESIC) is located in at the Denver Federal Center. The ESIC offers information and sales services for USGS map products and earth science publications. The ESIC can provide information about geologic, hydrologic, topographic, and land-use maps, books, and reports; aerial, satellite, and radar images and related products; earth science and map data in digital format and related applications software; and geodetic data. The ESIC can fill orders for custom products, such as aerial photographs and orthophotoquads, digital cartographic data, and geographic-names data. 


\section{Change Over Time}

As part of the Global Change Program, the USGS, in cooperation with seven counties in northeastern Colorado, is modeling land changes. Aerial photographs taken in 1937 that cover Adams, Arapahoe, Boulder, Jefferson, Larimer, Morgan, and Weld Counties are digitized, interpreted for land-use and land-cover characteristics, and compared with recent digital land-characterization data to determine change over time (fig. 3). The objective is to develop a method for predicting land-use and land-cover changes to determine possible effects on ecoregions and natural resources.

Another study in the Global Change Program is the Water, Energy, and Biogeochemical Budgets project. For this study, the USGS is examining sensitive components of the Loch Vale watershed in Rocky Mountain National Park to determine the likely effects of global change, which includes climate, on Rocky Mountain watersheds. An important objective is to study the interaction among snowpack, snowmelt, streams, wetlands, and glaciers and their response to warming or other aspects of global change.

\section{Collection of Hydrologic Data}

Colorado has four major rivers - the Colorado, the South Platte, the Arkansas, and the Rio Grande. These rivers supply water to users within Colorado and to many downstream States. The USGS, in cooperation with local, State, and Federal agencies, collects streamflow and water-quality data at sites throughout the State (fig. 4). These data are
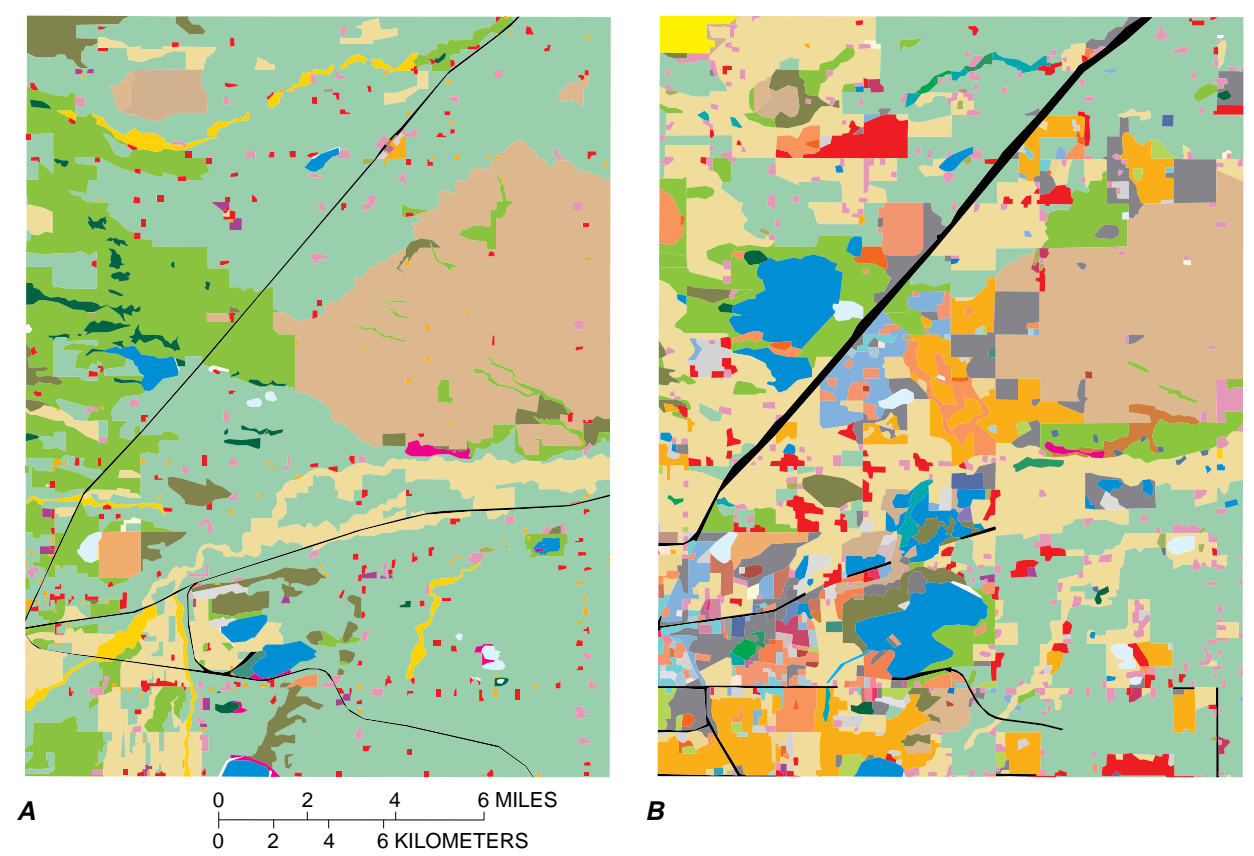

B

Figure 3. Land use in the Niwot, Colorado quadrangle, northeast of Boulder. A, 1937; B, 1982. Each color denotes a different land use type.

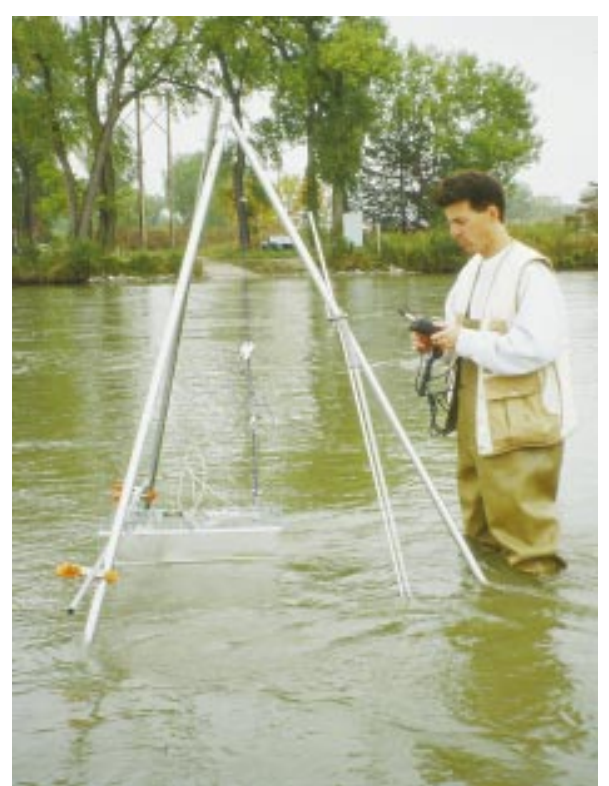

Figure 4. Water-sample collection.

critical for the day-to-day administration and management of water resources, determining the extent and severity of droughts, characterizing and predicting conditions during floods, and monitoring the effects of human activities on streamflow and water quality. The data also are essential to interpretive studies that provide information for making decisions about water issues that affect millions of people. Current (real-time) and historical water data for selected sites in Colorado are available by computer retrieval through the World Wide Web on the Internet. The Colorado home page address is:

http://webserver.cr.usgs.gov/
Additional earth science information can be found by accessing the USGS Home Page on the World Wide Web at http://www.usgs.gov/

For more information on all USGS reports and products (including maps, images, and computerized data), call 1-800-USA-MAPS

The USGS provides maps, reports, and information to help others meet their needs to manage, develop, and protect America's water, energy, mineral, biological, and land resources. We help find the natural resources needed to build tomorrow, and supply the scientific understanding needed to help minimize or mitigate the effects of natural hazards and environmental damage caused by natural and human activities. The results of our efforts touch the daily life of almost every American. 